\title{
The challenges of coordinating forest owners for joint management ${ }^{\text {in }}$
}

\author{
Elena Górriz-Mifsud ${ }^{\mathrm{a}, *}$, Luis Olza Donazar ${ }^{\mathrm{b}, \mathrm{c}}$, Eduardo Montero Eseverri ${ }^{\mathrm{c}}$, \\ Valentino Marini Goviglia

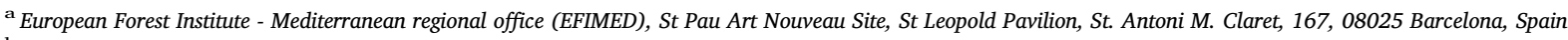 \\ ${ }^{\mathrm{b}}$ Union of Silviculturalists of Southern Europe (USSE), Spain \\ ' Forest Owners' Association of Navarra (FORESNA-ZURGAIA), Spain
}

\section{A R T I C L E I N F O}

\section{Keywords:}

Forest owner association

Joint forest management

Adjacency externalities

Social capital

Landscape-scale management

Spain

\begin{abstract}
A B S T R A C T
In a context of highly fragmented woodlands' ownership, joint forest management implies a reduction of transaction costs for its members and improves the coherence of forestry actions at the landscape scale. Increasing the size of the management unit improves market positioning, permits a more technical management, and improves environmental sustainability in aspects that require spatial coordination. A review of relevant literature on forest owners' groupings and the lessons learned from case studies in Navarra (Spain) have been analysed from a social capital perspective.

Twelve challenges are identified, for which technical recommendations are offered. We navigate through decision-making procedures, geographical cohesion, legitimacy and trust building, transparency and internal communication, trade-offs in efficiency and equity, local idiosyncrasy, management committee dynamics, risk aversion vs. flexibility, legal aspects, joint motivations and long-term vision, and intermediary's efficiency. Existing policy tools help in overcoming some of the economic and technical aspects. However, internal governance challenges require a concerted effort from participating forest owners.
\end{abstract}

\section{Introduction}

In Europe, most forest holdings span less than 10 ha (Forest Europe, 2015:178). In some countries, the average forest size is even smaller. Such fragmentation leads to problems for wood mobilisation and, generally, for profitability of traditional forest management at the individual holding level. In such contexts of fragmented ownership, Elyakime and Cabanettes (2009) and Koch et al. (2013) showed forest owners (FO) groups supplied wood more efficiently.

In addition, coordination of forest managers at landscape-scale allows ecosystem-based planning (Jacobson et al., 2000) and can tackle adjacency externalities, like wildfire prevention, plagues, invasive species or green corridors. Landowners' associations for joint forest management thus constitute a tool for effective landscape-level management, for more efficient forestry due to economies of scale (Aruga et al., 2013) and to provide stronger wood market positioning to participating landowners (Hansmann et al., 2016). Moreover, there is a perception of improved professionalism owing to the technicians overseeing the management group. These reasons mobilise some FO for collective action. Finley et al. (2006) found that nearly half of FO in a USA municipality would be agreeable to some form of cooperation. Also approximately $50 \%$ of private FO are willing to establish mushroom reserves with their neighbours in Catalonia (Spain) (Gorriz-Mifsud et al., 2017). Yet, interest in FO associations (FOA) is rather low in some Balkan countries (Pezdevšek Malovrh et al., 2015). Indeed, in most countries, coordinated forestry is still incipient and occasional - Austria leads with $37 \%$ of its private forest owners as cooperative members (Hägglund, 2008). The actual crystallisation of Joint Forest Management (JFM) may depend on various technical, financial and sociological barriers. Furthermore, forest groups are frequently expected to empower their members, to act as valid interlocutors, and to bridge the divide between owners and government forest policy; yet some groups achieve the opposite (Van Herzele and Aarts, 2013).

This review aims to identify the barriers for forest owners and managers to develop joint management schemes. For this purpose, we undertook a systematic review on joint forest management practices considering both theoretical and empirical knowledge (peer-reviewed articles, grey literature and JFM case studies). We used the term Joint Forest Management to refer to the cooperation of private forest owners on a scale larger than one (Kittredge, 2005), i.e. coordinated action among non-industrial private forest owners, each keeping their own landownership. Public owners may participate under the same

\footnotetext{
This article is part of a special issue entitled: "Forest ownership in multiple perspectives" published at the journal Forest Policy and Economics 99C, 2019.

* Corresponding author.

E-mail address: elena.gorriz@efi.int (E. Górriz-Mifsud).
} 
conditions as any other member landowner. This conceptualisation differs from other JFM definitions (chiefly in India), where the emphasis is on the co-management of the state forest authorities with local communities (Sundar, 2000). While this may fit in contexts of predominantly public ownership and centralised forest administration, our understanding better matches the Western European context.

With interpersonal relationships at the core of forest owners' coordination for collective action and value creation, our analysis of JFM takes the social capital perspective (Górriz-Mifsud et al., 2016). Social capital (SC) stands for the social relationships that affect the development of individuals (Coleman, 1988) and communities (Ostrom and Ahn, 2009; Pretty, 2003). It has been shown that networks, trust and reciprocity, power and influence, and informal control and sanctioning all affect the dynamics of collective action from their emergence to consolidation or demise (Ostrom, 1990; Pretty, 2003). Networks conceptualise agents amidst their constellation of different types of interactions, such as information sharing, formal or informal collaboration. Interactions occurring among people within a community make up the "bonding" social capital; these enable collective action through consensus building and conflict resolution (Bodin and Crona, 2009). Interactions occurring between members of different circles are referred to as "bridging" social capital; their interest relies on the diffusion of innovations. Finally, "linking" social capital represents the ties across different hierarchies; they are used to leverage resources and ideas beyond the community (Bodin and Crona, 2009). Moreover, network position matters: some agents hold stronger connections than others, and hence can exert certain influence over the flows within the community (e.g. town mayor, local opinion-leaders).

People's relations are often expected to be reciprocal. Agents' interaction provides opportunities to confirm expected behaviour, acting as a form of social control. Recurrent interactions with such informal supervision set the basis for trustworthiness and develop a reputation ("relational" social capital). Consequently, being part of a network gives its members access to information about others that reduces information asymmetries. Lowering informational asymmetries in turn decreases the chances for free-riding and facilitates (collective) agreements for action (Ostrom and Ahn, 2009). SC value, then, resides in the savings due to reduced formal controls, faster joint decisions, and risk pooling among individuals that trust each other (Bowles and Gintis, 2002). Yet, these aspects are also complemented by other non-SC factors relevant for JFM.

FO organisations for JFM require activating social relations while aligning different interests and expectations. Rural communities using these relations for their development hold a high and positive social capital (Coleman, 1988). Social capital is useful at both the individual and collective level, which can positively lead towards monetary benefits (e.g. more bargaining power) and non-monetary benefits (e.g. recognition), but also negatively towards the so-called "dark side of the social capital" (e.g. mafias).

But besides the critical mass of engaged FO, the survival of Forest Owners Associations (FOA) and their prosperity depends on political support, services for their members, and visible success in influencing policy (Glück et al., 2010; Sarvašová et al., 2014). Despite the verbal support of associational thinking, the organisations receive relatively little public funding (Schraml, 2005). Moreover, flourishing cases of collaborative natural resource management have shown the need for forest service staff acquiescence and follow-up, as well as incentives and rewards for entrepreneurial members focusing on these collaborative objectives (Wondolleck and Yaffee, 2000). For all these reasons, we analysed the challenges identified with existing policy tools in the Spanish legal framework.

\section{Material and methods}

\subsection{Objectives of the review}

The objective of our review was to examine the challenges that JFM faces in achieving its promised benefits, both from an implementation (e.g. FO members, technician responsible for association) and policy standpoints. Consequently, our guiding research question was: "which practical challenges do forest owners and practitioners face to implement JFM?" Building on the previous results, a consequent policy question was: "how do current policy instruments help overcome these challenges?" We analyse the Spanish context, which includes very fragmented private ownership and diversity of regional policy tools to promote JFM.

\subsection{Systematic literature review process}

According to the guidelines for Systematic Reviews in environmental management (Collaboration for Environmental Evidence, 2013), the primary question was broken down into its PICO (Population-Intervention-Comparator-Outcomes) components to clarify the scope of the systematic review. Our Population are forest owners working as a group and group technicians (when applicable). These aggregations can encompass associations, cooperatives, informal voluntary unions and enterprises. We have hence, excluded articles presenting management options dealing exclusively with individual forest owners. Intervention is the governance regime of coordinated management of forest resources according to the abovementioned JFM definition. In terms of Comparator, we focus on the individual forestry regime. We then assess the challenges the individual faces when entering a group, which entails the modification of the decision-making process and management strategies. Lastly, for Outcomes we considered the challenges regarding internal and external dynamics that JFM practitioners face in implementing the coordinated management.

The review process (supplementary material 1) started with a search of the terms: forest management AND Private AND *owner* AND associat* OR joint* OR collaborat* OR *group* OR cooperat* OR co-op* in SCOPUS ( $N=478$ different entries, restricting to title, abstract and keywords) and GoogleScholar $(N=220)$. The first filter of the review (i.e. duplicates' removal, abstract and title screening) was undertaken by one author. By reviewing the actual content, we discarded the articles where FO organisations and collaboration were not explicitly addressed as a main topic, as well as the references to collaborative forestry in the sense of community or participatory forestry. This resulted in a selection of 58 articles. Some additional relevant publications $(N=28)$ were later added as per snowball emergence from analysed papers. 86 articles were then analysed (see supplementary material 2). In order to ensure consistency in the identification of JFM challenges, the complete text screening of articles was conducted by three reviewers.

Most papers are based on case studies that focus on how the association emerged (e.g. FO motivations to join and to manage jointly, barriers) and works (e.g. joint sales' efficiency, information/training, participation in policy programmes). These papers employed a range of qualitative and quantitative methods, and are generally relating to Western societies (Europe, USA, Australia and Japan). A miscellaneous terminology ${ }^{1}$ is used to refer to sometimes coincident phenomena, most likely due to the direct translation from the national language of the case study. No standardised terminology exists (Hägglund, 2008), and hence careful attention was paid to determine the possible nuances in their governance arrangements. For this reason, we begin with a comparative analysis of the types of forest owner groupings.

After all relevant documents were reviewed, we enriched the literature review findings (identified challenges) with two case studies of forest owner groupings in Navarra (Spain). The groupings were managed by FORESNA, namely: a dispersed forest owners' group in the

\footnotetext{
${ }^{1}$ Cross-boundary cooperation; joint forest planning; interest group; forestry cooperative; forest owners' associations; forest management association; regional group; jointly owned forests; management group, FO club; concerted management; forest consortium, forest producer organisation (see Table 1).
} 
Pyrenees (Roncal, 2014-ongoing); and another of similar geometrical parcels ("quiñones", Ibargoiti 2011-ongoing). Participant observation from the scientific authors and direct management from the practitioner authors provided the data. To this aim, three expert interviews, one focus group meeting with local technicians, one field visit with prominent FO members (president, treasurer, secretary), and the observation of four assemblies were used to validate and complement the JFM challenges stemming from the literature review.

\subsection{Data analysis}

An inductive-deductive approach was used for content analysis. An initial deductive set of codes was produced from Social Capital theories on personal network management (trust, communication, power distribution, risk sharing).The researchers coded parts of the literature accordingly; however, new factors emerged which affect the JFM process and outcomes. With the literature findings and the lessons learnt from the case studies (i.e. good practices and policy or practitioners' recommendations), we analysed the information based on the challenges that forest owners and practitioners face when developing a JFM. The list of challenges was built iteratively so that when a new challenge emerged, the articles were revisited in order to find possible references to it. This step resulted in 14 challenges, which were finally refined into 12 by merging those dealing with similar aspects.

\subsection{Policy analysis}

Conducting a comprehensive, global review of policy tools aimed to support JFM is beyond the scope of this paper, as it would deserve an article in itself. Yet, by expanding out from Navarra to the wider Spanish context, the authors benefit from the variation across Spain's autonomous communities, which offers a wider array of policy instruments to analyse. The list of challenges was assessed against existing policy tools underpinning JFM across Spanish jurisdictions. In the current Spanish context, JFM is deemed necessary (as stated by the Spanish Forest Act of 2003) owing to the large fragmentation of private forest estates: $84 \%$ of the 19 million hectares of forests corresponds to family owners. This implies over 5.2 million forest owners, $99 \%$ of whose parcels are smaller than 10 ha (Rojo Alboreca, 2013).

We reviewed legal figures and incentives occurring in Spain at State and regional level that affect JFM. This step entailed content analysis of legal documents as well as implementation reports. As a result, five main policy tools were identified that (at least partially) tackle JFM initiatives. Based on their content and available implementation indications, the authors assessed whether the instrument:

- helps in overcoming each challenge (positive effect);

- aggravates the challenge or incentivises individual forestry (negative effect);

- only has potential effects when it is specifically designed;

- does not have an effect on the challenge (not applicable).

\section{Results and discussion}

\subsection{A portfolio of collective action options}

The efforts of forest owners to join up with each other crystallise in different types of organisations, depending on member demands, organisational capacity and consequent target activities (Mendes et al., 2006) (Table 1). We first differentiate between profit-oriented entities and non-profit oriented, which determines the legal status of the entity. Non-profit entities are generally established as associations. Those that are profit-oriented can be directly constituted as owners' companies or can be a branch of an association, which offers business services to members. Non-profit range from chambers of agriculture, to interest groups for political action (Hägglund, 2008), to associations for forestry

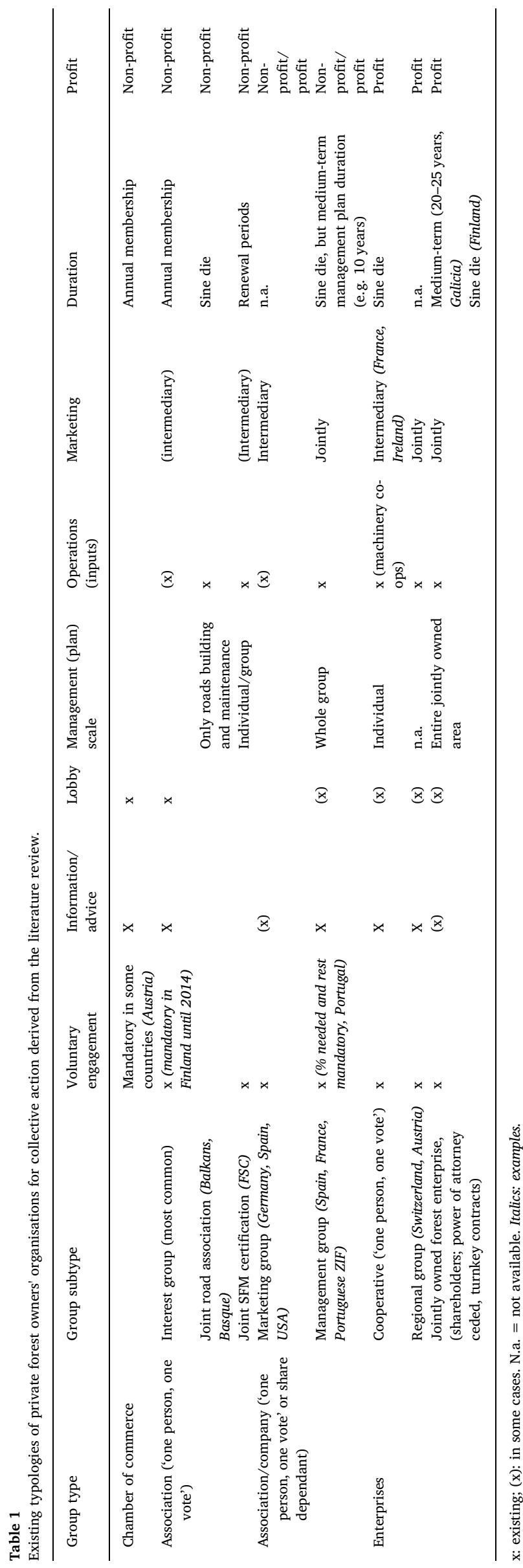


information and training services, or for overseeing the land restitution process -e.g. in Central East European countries (Bouriaud, 2007; Sarvasova et al., 2015). Some entities go further and offer the FO to conduct some critical forestry tasks collectively: joint commercialisation of products, e.g. Austria, Sweden (Bouriaud, 2007); group certification of sustainable forest management (Ota, 2007); better use of public subsidies, e.g. Portugal, Ireland (Mendes et al., 2004); risk prevention (Canadas et al., 2016; Couture et al., 2016; Fischer and Charnley, 2012; Prokofieva and Górriz, 2013); machinery co-ops, e.g. in Scotland, France; or joint development of roads, e.g. Basque country, Balkans (Avdibegović et al., 2010). This can take the form of cooperatives if the decision-making power is independent of the contributing forest, or act as a regular company otherwise. A further step is ceding power of attorney to an entity for general joint forest management, or to a jointly owned company if profit-oriented, e.g. in Finland, Ireland.

The institutional arrangement of these organisations depends on the services they provide, which seem to undergo a natural evolution in terms of property rights delegated by the FO (Milijic et al., 2010; Sarvasova et al., 2015; Schraml, 2005). In this sense, FO members would progressively develop organisations to reflect a growing willingness to cede ownership control, from a mere representation of interests, to management rights (e.g. planning: objectives, strategies, operational aspects; marketing), as far as extraction rights (e.g. harvesting decisions: when, tree marking). FOs compensate such loss of property rights through legitimated reasons (Lähdesmäki et al., 2016). FO groups are generally legitimised through the economic and noneconomic benefits of the collective action of landholders with small forest size. However, empirical studies show that small FO are most likely members of JFM groups in some countries (Eggers et al., 2014), while in others this specific group of landowners is not predominant in JFM organisations (Põllumäe et al., 2014; Schraml, 2005).

Also, common pattern is that FO with an agricultural background and larger income expectations from forests are more likely members of JFM entities (Rodríguez-Vicente and Marey-Pérez, 2009), and tend not to be the passive FO type. While most of these organisations are voluntary, some countries may require forest owners' membership, as it happens in Austria with the Chambers of Agriculture (Weiss et al., 2015) or until recently (2014) in Finland (Karppinen et al., 2015). Some motivational aspects - such as desire for property rights' control or privacy - can become insurmountable barriers to cooperation, thus precluding the voluntary engagement of a share of the FOs (Finley et al., 2006). Moreover, non-members often enjoy the collective benefits of the political action and aggregated management financed by their neighbours, hence behaving as "free-riders" (Nonic et al., 2011). Mandatory membership is suggested in Slovenia and Serbia as a way of influencing the smallest and passive forest owners to achieve socially desirable goals (Pezdevšek Malovrh et al., 2015). Yet, a substantial part of landowners disagree with obligatory membership (Nonic et al., 2011).

We focus on the cross-boundary collaborative management level; these are the cases where landowners have to agree to the management plan and its implementation. The jointly owned enterprise implies the largest form of integration and collaboration among forest owners, where the strongest driver is economic profitability. We rather take the wider perspective of joint forest management as a lesser level of integration, where landowners' motivation may not necessarily be economic (e.g. recovery of family patrimony, preventive measures for pests and wildfires). Yet, some aspects of group dynamics may apply across different typologies of FO organisations. In JFM, the forestry strategy is conducted at landscape scale where forestry criteria have to dovetail with the expectations of the individual landowners. Usually, these expectations include sharing the planning, forestry workers and equipment, forest roads, marketing, or financing. Often, the large burden of work implies that a professional forester takes charge of the operational aspects while the management board and the members' assemblies take the strategic decisions. The main differences with community forests are: i) voluntary engagement, whereas community membership is generally acquired with town registration or family links, and ii) FOs keep ownership rights to the specific pieces of land, whereas in community forests members are shareholders without a concrete piece of land.

\subsection{Challenges for joint forest management}

Taking the perspective of a forest technician aiming for effective joint forest management, twelve aspects have been identified as key challenges, as follows.

\subsubsection{The procedure for making decisions}

Individual scope for forestry decision-making comes at the cost of the FOA span of activities (Schraml, 2005). Group decision-making is hence critical, given that all group members lose some decisional power over their forest holding (Lähdesmäki and Matilainen, 2014). Some profiles of forest owners may easily conform to a new governance system with delegated activities; for example, FOs who live far from the forest in a more urban context or with alternative sources of livelihood, constitute potential members of largely integrated management groups. At the opposite end of the spectrum, full-time farmers or pensioners living in rural areas may be better positioned to retain and directly manage their pieces of land (Schraml, 2005). Moreover, some landowners may be ready to cooperate only on certain aspects and withhold some property rights. For example, Finley et al. (2006) clustered forest owners with interest in cross-boundary cooperation into two groups: those driven by non-utilitarian dimensions (e.g. entailing conservation restrictions or wildlife habitat management); and those with rather utilitarian motivations (e.g. sharing the management plan, trails and marketing).

Reaching consensus might be difficult in contexts of heterogeneous preferences (Lidestav and Arvidsson, 2012). Agreeing on how decisions are made provides legitimacy and acceptance. Operational decisions are delegated to an executive board and manager while holding periodic general assemblies for strategic decisions. Usually strategic decisions (e.g. management plan, budget, negotiations) are taken by the general assembly, on the basis 'one person, one vote', independently of the forest area owned (Dedeurwaerdere, 2009) applying a majority rule in voting. Some decision-support tools are being developed to facilitate joint decision-making for multiple holders (Eyvindson et al., 2011). These aspects are reflected in the legal form of constitution (e.g. non/ for-profit), the statutes, and the internal working norms (control, infractions, sanctions, membership termination). Internal rules are important for the dialogue between the elected executive bodies and members to secure internal stability (Sálka et al., 2016). Yet, these legal aspects might imply barriers according to each country regulations (Navascués Ramos and Llobet Just, 2007; Weiss et al., 2012).

\subsubsection{Fiscal and legal aspects of business models}

The different legal and patrimonial consequences of each legal layout (Cots and Viñas, 2013) have to be considered from the perspective of the group ambition. Has the group been established ad hoc (e.g. for post wind/snow storm restoration), is it a more stable, nonprofit association (i.e. acting as mere intermediary, such as consortia for mushroom reserves), or is it a for-profit cooperative or joint venture (e.g. for biomass supply to a local bioenergy plant, or for the global management of forest products)? Associations are the most common choice, owing to its flexible legal figure, with simple rules, relatively low number of initial members, very small initial capital, and simple closing down procedures (Mendes, 2006:295).

\subsubsection{Communication channels}

Communication is strongly relevant, given that it is one of the key motivations for joining associations (Pezdevšek Malovrh et al., 2011). 
Reaching all members usually requires large efforts but is also conducive to better results. A balanced approach should select appropriate means depending on owners' profiles (e.g. email, phone calls, mail), so that information can flow from the group to their members in an efficient manner. Strong communication efforts are foreseen at inception, and with members' engagement growing, as they evolve from being passive receivers to active searchers.

Each communication channel has its pros and cons, so the basics start with determining how local social networks spread information. Social network analysis helps identify the local "hubs" ("bonding" social capital) - whether a physical location, like a school or social centre, or a specific person, such as the mayor or town secretary - which efficiently distribute information among (potential) members. Time barriers have emerged as important (Kronholm and Wästerlund, 2013); therefore, convening group meetings when members' availability is high may not necessarily fit with the technicians' working hours (e.g. evenings, holiday periods or weekends), but can efficiently gather a larger and more varied critical mass.

"Peer-to-peer" learning (e.g. through field visits) also proved to be relevant in cases of new issues or technologies: landowners learn from the experience of someone similar to them (Kueper et al., 2013; Schubert and Mayer, 2012), reinforcing their "bridging" social capital and, consequently, their sense of interdependence (Wondolleck and Yaffee, 2000). Moreover, involving local politicians usually helps smooth some practical group needs (e.g. logistics) but can also better connect with supra-municipal bodies (the "linking" social capital), who may ultimately help with implementation. Relevant to the local-level acceptance of the JFM initiative is the identification of complementary, non-political opinion leaders; taking into account their opinion and suggestions regarding the JFM endeavour can help to keep their position regarding the proposal neutral or positive.

Content-wise, forest technicians responsible for group management bridge the technical and informal language domains. They have to be prepared to explain and clarify the latest technological innovations as well as basic forestry concepts. System thinking, rather than linear thinking, may seem complicated to transmit, but, with time, enables better comprehension of the nature of some of the more difficult problems the group may face. Empathy and reflection is required to adapt to the members' context, especially when it is necessary to dismantle "myths" in order to progress with the group work.

Style-wise, thriving collaboration cases show the need to orient members' discussions into problem-solving debates rather than blaming, to focus on interests and not positions, and to define problems not as a "single-solution" but allowing for creativity (Wondolleck and Yaffee, 2000).

\subsubsection{Geographic cohesion}

Traditionally, associations appear through voluntary subscriptions, which often results in discontinuous areas. That implies reduced effectiveness for forestry works and other objectives (e.g. fire prevention). An alternative approach entails selecting a key zone and attempting to convince landowners to manage it jointly. This usually requires an invisible but labour-intensive task of searching in the cadastre - whose publicly available information is often restricted - and then contacting each landowner. Such intense labour is often a barrier, which could, for instance, be covered by public funds based on the resulting positive externalities of the JFM. This occurs with the Portuguese Forest Intervention Zones (ZAF), where the Green Fund partly finances the geographically cohesive FO groups (Canadas et al., 2016).

Convincing potential members is challenging, hence convincing targeted ones results in an even more difficult task. In some countries a clear lack of interest is predominant (Sarvasova et al., 2015). Leaderfollower patterns usually apply (i.e. relying on informal network spread, mimicking). If the financial incentives are a functional tool, adjacency criteria for economic returns may serve as a carrot to join.

\subsubsection{Trust and transparency}

Confidence (i.e. "relational" social capital) is necessary to work together. Unwillingness to cooperate has been reported in some cases due to lost trust based on previous negative experiences (Põllumäe et al., 2016). Trust may contribute to the decision to join the group as a type of authorisation/legitimacy strategy (Lähdesmäki et al., 2016). In forest owners' groups, trust relationship affects three types of interactions: among members, towards the intermediaries (e.g. technicians) and in the institutions (e.g. town council, public agencies). Trust is the easiest aspect to lose and the one that takes longer to build.

Confidence in foresters is based on the perception of professionalism, which in turn depends on their reputation and the forestry knowledge pool of members. Trust in technicians is key insofar as they are reference points for choosing management strategies, e.g. participating in subsidy lines or conservation programmes, or adopting certain silvicultural itinerary (Eggers et al., 2014; Primmer and Karppinen, 2010; Van Gossum et al., 2005). Furthermore, forest owners facing high uncertainty (e.g. wood price fluctuations, climate change) and complexity (e.g. technical interrelations with geopolitics) rely on trustworthy people and organisations, adopting their mental models (Schlüter and Koch, 2009).

The progressive implementation of the JFM strategy, from easier decisions to more delicate ones contributes to build the necessary complicity that ensures trust. Trust is also built (or questioned) through recurrent interactions. Recurrent meetings bolster interaction among members, establishing new "weak ties" with unknown people and reinforcing "strong ties" with known ones. Face-to-face meetings allow knowing the others, perceiving their interests and assessing their reliability. Rodríguez-Vicente and Marey-Pérez (2009) showed that association members tend to talk with closest members and technicians (strong ties) and consider the rest as trustworthy (weak ties). Both types of ties facilitate joint decision-making.

Easy access to group information contributes to creating and maintaining trust (Kronholm, 2016). However, confidentiality and discretion with personal data and individuals' forest information are required to comply with confidentiality regulations, but also to avoid interference with local diplomacy. Secretariat and treasury tasks become crucial for transparency, reflecting decisions, costs and revenues. Hence, treasurer and secretary are generally trustworthy persons within the local community, as witnessed by their professional activity - e.g. teacher, bank officer.

\subsubsection{Fairness versus efficiency}

A balance between these two criteria is required when making decisions such as splitting costs and prioritising actions. Efficient (Paretooptimal) management decisions sometimes entail collective benefits but are detrimental for a member. E.g., a shared forest trail can be more efficiently opened by using the space of a single landowner, which reduces their future silvicultural possibilities, while the neighbours benefit substantially. Over the course of the negotiation, the technical criterion, as external agent, can help the collective interest prevail over the private, which may block management viability. Consented compensation mechanisms that internalise such negative effect within the group are needed. Kronholm (2016) also reported some strategies for achieving group acceptance by price bonus to some landowners, which will in turn benefit the overall group.

\subsubsection{Local idiosyncrasy}

The local savoir-faire (informal norms, codes) is relevant for cultural immersion and selecting business models (Ambrosio Torrijos et al., 2003). Yet some dynamics may hinder better functioning of the group, requiring reasoned explanations. For example, in some areas, verbal agreements prevail over formal contracts. Other unwritten codes to consider include protocols for involving the local powers that be or setting the correct tone for meetings. One of the barriers facing forest owners' cooperation is the conflict between formal institutions and 
informal forest owners' institutions (Põllumäe et al., 2016). It should be clearly justified why a certain informal working manner is not feasible within the group (e.g. signatures needed). As a result of joint working, over the course of time, some working procedures may evolve and some traditions may be challenged when new principles emerge (e.g. gender roles).

\subsubsection{Flexibility and risk aversion to long-term commitments}

FOs are more likely to adopt shorter commitments in management plans (Klosowski et al., 2001). In terms of harvesting decisions, FO's tendency to risk-aversion implies shorter rotation periods (Couture et al., 2016). In terms of wood sales, long-term timber lease contracts in USA generate doubts among potential partners (McGill et al., 2008). This shows that uncertainty and novelty usually generate concerns among potential members, who prefer flexible group contracts with progressive commitments. This entails a recurrent review of the agreements, which can be costly on the one hand, and on the other, can hinder the medium- and long-term vision of the JFM group. For example, if the organisation acts as a mere wood dealer with soft commitments for joint marketing, it can lead to opportunistic behaviour if the FO finds a better price unilaterally with another dealer and passes over the grouped trade, consequently affecting the entire group. Some authors suggest an initial trial enrolment to reduce uncertainty (Klosowski et al., 2001). Others suggest mechanisms for flexibility such as including sanctions in the statutes that compensate the other members if a FO breaches their commitments before finalising a certain period.

\subsubsection{Involvement of members in the executive board}

Members who voluntarily engage in a directive role must be elected by members and work for the common interest (Mendes et al., 2011). These members usually show greater forestry knowledge than the rest and have leadership tendencies. Yet, fully voluntary organisations may be less operative than those with a professional forester (Sálka et al., 2016). Such profound involvement means greater decision-making power as well as time devoted by landowners. Rotations in the executive board help to overcome the potential burn-out of enthusiastic leaders over time, and to avoid "cacique"-type dynamics in long-term governance. A compromise is to be found between the fatigue of contributing executives and the efficiency and experience of rather stable positions (Kronholm and Wästerlund, 2013). Topic-specific working groups can introduce intermediary involvement. Yet, the evidence shows that urban FO are the most difficult to engage in these honorary positions (Schraml, 2005:260); so, targeting these profiles may require a smart strategy to make it attractive and push them to more frequent interaction with the rural area where the forest is located.

\subsubsection{Windows of opportunity}

Natural disturbances or social changes are often triggers for landowner social interactions (Bodin and Prell, 2011), as a result of which, previously "inactive" FO are "transformed" become "active" managers. This is the case for eventualities affecting a large group of landowners (e.g. pest, fire), which sometimes function as a motivator for people to work together: common interests constitute trigger factors for grouping individuals. Hence, analysing local FO motivations for forest management becomes crucial for understanding typologies of landowners. Such information allows group managers to develop strategies to encourage potential members, to align their demands towards a common project, and to manage elements of cooperation among forest owners over individual preferences (Kittredge, 2005). For example, the benefits of coordinated action might not necessarily be visible for some potential members, and thus require targeted explanation (Rickenbach et al., 2006). In terms of motivational dimensions, Domínguez and Shannon (2011) found four axes for management decisions, namely: economic expectation from the holding; feelings of moral duty; a model of how the forest should look like; and the attitude to natural risks. By determining the relevance of each dimension for landowners, opportunities emerge on how the JFM can cope with those perceived as unfulfilled. For example, in contexts of low wood profitability, the criterion of landowners is often "to improve risk prevention, implying little or no net expenses and, if possible, extracting some net revenue".

\subsubsection{Efficiency of the intermediary}

Efficiency is required for group management, and is, in turn, linked to transaction costs derived from: (i) documenting forest owners' contacts; (ii) approach to contract forestry works; (iii) landowners' proximity to their forest; (iv) method to reach agreements. Efficiency is higher if the authorities can rely on accurate, updated and somehow accessible tools (e.g. cadastre, land registry). The efficiency of FOA has been questioned, and some neo-institutionalist scholars rather highlight the efforts of organisations to win legitimacy in this aspect (Schraml, 2005).

\subsubsection{Attractive long-term vision}

Interest in management coordination is a first step in developing relationships with and among FO (Finley et al., 2006). Such interest is generally channelled through the JFM prospects, which triggers the voluntary engagement of FOs. Yet, experience shows typically poor economic results in the beginning, with evident success in the long-term by improving forest stand quality (Brabänder, 1981). Hence, a shared understanding of the mutual side benefits of joint management (e.g. infrastructures, holding clarification) helps overcome initial problems, especially when economic return is not high. In Navarra, the initial 10years of group management is meant to bring the stands "up-to-date", i.e. starting a silvicultural strategy to improve the forest status and capitalise the stands.

Conviction that the benefits from being in a group will outweigh the costs, expectation that the forest will be better cared for with the involvement of a professional technician or the legacy for the next forest owner generation may be relevant motivations for landowners to join the group (Lähdesmäki et al., 2016). Therefore, JFM group managers are recommended to develop joint vision statements to encourage the group approach (Wondolleck and Yaffee, 2000). Such vision may build on FOs' shared sense of place (i.e. moral attachment to the specific territory, (Berlin et al., 2006)) and would ideally take into account potential side benefits. Indeed, uniquely focusing on timber sales may not necessarily attract certain profiles of FOs, especially if no additional services are offered by the JFM groups (Kronholm, 2016).

This is especially relevant, as professional forest managers tend to think that FOs place more value on traditional forest services (wood supply, family traditions) and less on environmental and recreational functions than is actually the case (Kindstrand et al., 2008). Campbell and Kittredge (1996) attributed a failed pilot project on joint ecosystem-based forest management to the motivation of private consulting foresters prevailing over that of the enthusiastic participating landowners. Some discrepancy may thus bring about conflict owing to diverging perceptions on values and attitudes (Eggers et al., 2014). Assemblies using techniques such as dynamic agendas help retain members' interest over time. For example, presenting trending topics that are important to member owners shows that the technician does not bring his/her own agenda, but instead adjusts to landowners' interests.

\subsubsection{JFM challenges discussion}

Twelve success factors from legal, administrative, communication, social and economic aspects have been identified from the review of previous scholarly work. Some of these challenges are based on aspects of social capital (e.g. trust building, flexibility and risk aversion, internal communication). Yet, others correspond to the internal governance of the group and its implementation. Constituting a group of FO for JFM implies setting up a new institution, so this can be also examined through the lens of institutional analysis. From such a 


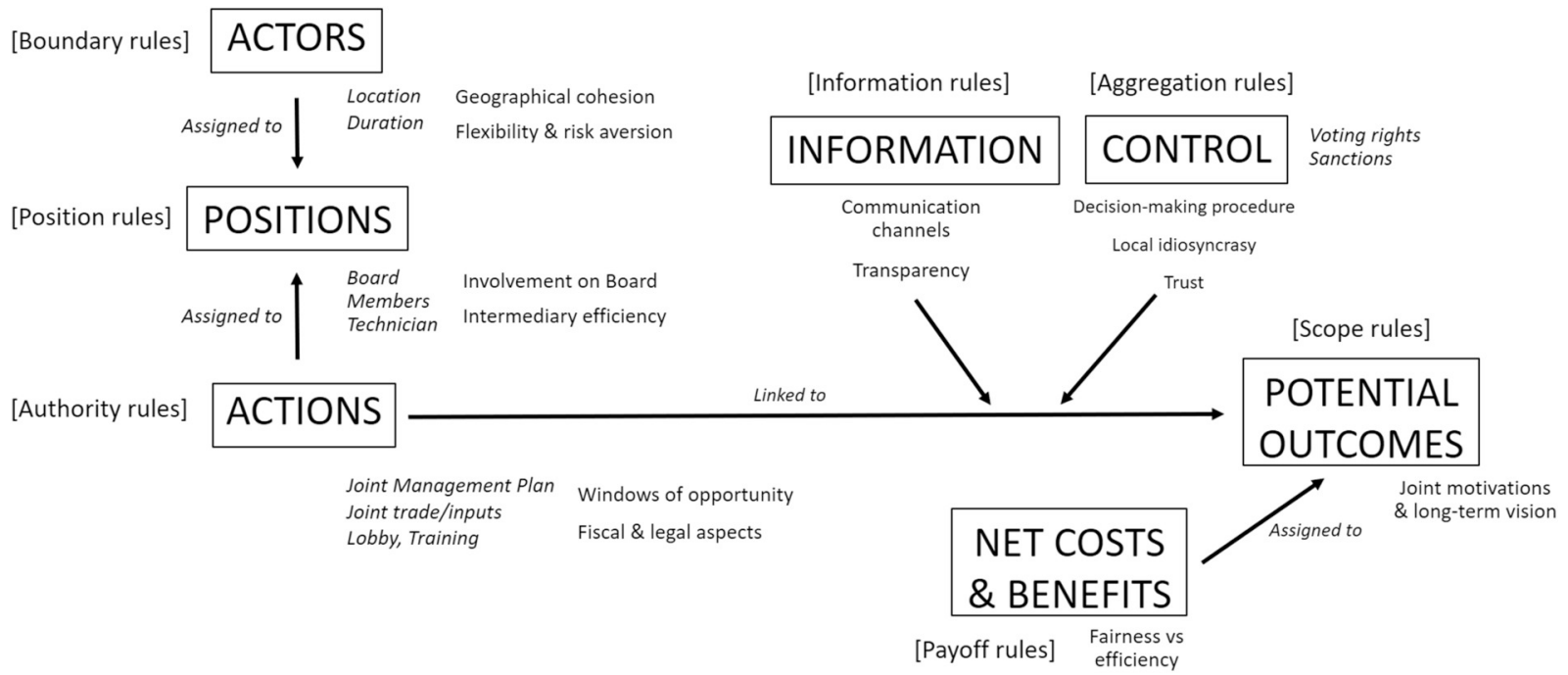

Fig. 1. Conceptual framework for joint actions, with ist elements (boxes), their related working rules and the identified JFM challenges.

Adapted from Ostrom (2010).

perspective, some of the identified challenges support the working rules of repetitive action arenas as conceptualised by Ostrom (2010) - see Fig. 1. Actors are affected by boundary rules, which delimit the scope and profile (i.e. attributes) of participants, and the conditions they face for entering and leaving (Ostrom, 2005:834). The location of the group members' forests would determine the geographical cohesion for JFM, while the duration of their commitment with the group would determine flexibility and consequent risk aversion. Position rules assign the role of actors, which determines the dynamics of the JFM board and the intermediary efficiency. The tasks expected for each position are shaped by authority rules, which depend on the fiscal and legal configuration of JFM, and may be triggered by windows of opportunities. The internal communication flow across actors (i.e. channels and content shared across JFM members) relies on information rules, which determine transparency. Aggregation rules refer to "the level of control that a participant in a position exercises in the selection of an action" (Ostrom, 2005:834), and thus determine the legitimacy of the decisionmaking procedure, and in turn depend on local idiosyncrasy. Scope rules characterise the expected outcome, which drives the joint motivations and long-term vision. Finally, how members split the costs and benefits related to the process and outcomes (i.e. pay-off rules) delineates trade-offs in efficiency and fairness.

\subsection{Policy tools in Spain supporting joint forest management}

The principal instruments used to support JFM to break down existing barriers often take the form of economic incentives. Such stimuli, if addressed properly, could foment the development of joint management plans. Pezdevšek Malovrh et al. (2015) and Põllumäe et al. (2016) underline how cooperation among FOs could be bolstered via a set of policy instruments tailored to different classes of FOs (active vs. passive and uninterested; multi-objective vs. mono-objective; public vs. private), which might require diverse incentives for cooperation.

Although economic instruments are widely recognised as most effective, especially for active FOs, there is a growing interest in the pivotal role played by informational and motivational instruments, which could indeed be as adequate as economic tools to initiate joint activities (e.g. open day events, informational campaigns, workshops and meeting with experts) (Pezdevšek Malovrh et al., 2015).

Five policy tools were identified that (at least partially) tackle JFM initiatives in Spain and its regions:

- specific subsidy lines for joint forestry;

- prioritising subsidy applications from groupings;

- increasing subsidy rates for groupings;

- public provision of group facilitation;

- "Forest society" legal entity.

Table 2

Policy tools to bolster joint forest management and its relation to the JFM challenges.

\begin{tabular}{|c|c|c|c|c|c|}
\hline \multirow[t]{2}{*}{ Challenge } & \multicolumn{5}{|c|}{ Existing Spanish policy instruments } \\
\hline & Specific subsidies & Subsidy prioritisation & Subsidy bonus & Public provision of facilitation & Forest societies \\
\hline Procedure for decision-making & $(+)$ & + & + & $(+-)$ & + \\
\hline Fiscal and legal aspects of business models & $(+)$ & + & + & n.a. & + \\
\hline Communication channels & n.a. & n.a. & n.a. & n.a. & n.a. \\
\hline Geographic cohesion & $(+)$ & $(+)$ & $(+)$ & n.a. & $(+)$ \\
\hline Trust and transparency & + & n.a. & n.a. & + & + \\
\hline Fairness versus efficiency & n.a. & n.a. & n.a. & + & n.a. \\
\hline Local idiosyncrasy & + & + & + & $(-)$ & + \\
\hline Flexibility and risk aversion to long-term commitments & + & $(+)$ & $(+)$ & n.a. & - \\
\hline Involvement of members in the executive board & n.a. & n.a. & n.a. & - & n.a. \\
\hline Windows of opportunity & + & + & + & + & + \\
\hline Efficiency of the intermediary & n.a. & n.a. & n.a. & $(-)$ & $(+)$ \\
\hline Attractive long-term vision & $(+)$ & $(+)$ & $(+)$ & + & $(+)$ \\
\hline
\end{tabular}

+: positive effect; - : negative effect; () stands for potential effects; n.a.: not applicable. 
In the following table, each tool is analysed in relation to the identified challenges (Table 2).

\subsubsection{Subsidies}

Subsidies, as monetary incentives, are a common tool for incentivising cooperation and joint management practices with the aim of reducing costs that need to be shared among partners. They also incentivise a smarter selection of activity types by balancing out individual risk aversion. Subsidies can be designed in a variety of ways according to their targets. They can be lump-sums, but the tendency is towards activity- or item-based grants that can be justified. Cost-sharing grants help in strengthen FOs' commitment, but may become a barrier in low profitability forestry projects, such as fire prevention measures (Canadas et al., 2016).

3.3.1.1. Specific forest grouping subsidy lines. Subsidies can also be tailor-made to encourage JFM. Examples of such a tool could be found in Asturias or Catalonia on an annual basis, and only occasionally in Valencia. In some cases, they are circumscribed to specific activities (e.g. biodiversity preservation, risk management). They can also include clauses of geographical connectivity through distance thresholds to encourage adjacency or at least participants with nearby forests. In Catalonia, subsidies for restoring forests after catastrophic events of wind- and snowstorms have been targeted exclusively to FO groups. Further specific subsidies along these lines are foreseen through the Rural Development Programme, specifically measure 8 for bolstering producers' groups -Article 27 of EAFRD (UE, 2013). On some occasions, these subsidies include the need to provide advisory services to members (Hansmann et al., 2016). Indeed, FOA are progressively offering more services to deal with the lack of a public extension service. In some countries (e.g. Germany) these services were previously state-provided (Schraml, 2005); the current trend is towards outsourcing, which legitimates FOA to request public resources to fulfil this role.

As a bottom-up approach, specific subsidies adapt well to the local idiosyncrasy, if there is critical mass and self-organizing capacity. Annual calls are reassuring, reducing risk aversion to long-term commitments and consequently supporting flexibility requirements. By including or maintaining this incentive tool in their agenda, the government shows commitment to group work, which improves institutional trust. Specific subsidies can also galvanise cooperation, taking advantage of windows of opportunity posed by catastrophes (e.g. fire). Subsidies addressed to a specific legal entity (e.g. legally constituted or ad-hoc, associations or cooperatives) might influence the group business model, and thus the decision-making procedure and fiscal aspects.

3.3.1.2. Prioritising/increasing subsidies for groupings. All FO are eligible for such subsidies, but they tend which reward groupings through a bonus or their prioritisation in the selection process. In a context of scarce budgets and numerous subsidy applications, group prioritisation implies that membership becomes crucial for eligibility in practical terms. Examples of these schemes are SFM subsidies in Catalonia (some years with group prioritisation, others with premium) or aids for forestry works in Navarra. Yet, there are no examples of adjacency bonuses, which could be extremely useful to tackle adjacency externalities (e.g. green corridors, strategic firebreaks).

In terms of JFM challenges, they trigger joint decision-making processes while adapting to the local idiosyncrasy. They may also facilitate fiscal and legal aspects, depending on the specific subsidy requirements (e.g. long-term commitment, legal form). They might additionally improve the geographical cohesion of the unit, if they provide a proximity/adjacency bonus, and develop a stronger long-term vision addressing risk-taker FOs.

\subsubsection{Public provision of joint management facilitation}

Public provision stands for the JFM schemes initiated by the public sector, that is, when the forest service allocates specific personnel to promote and manage JFM groups (Schraml, 2005). The government has a large degree of influence over the JFM decision-making, which is likely could address government interests rather than those of FO's. This could harness local idiosyncrasies. It shows strong government commitment, and generally aims to tackle geographically cohesive groups in view of landscape-scale management planning, with its consequent forest externalities. This tool has been implemented by the provincial government of Barcelona for supporting groups addressing fire prevention (Navascués Ramos and Llobet Just, 2007). Alternatively, the facilitator task can be outsourced through framework contracts between the administration and existing FOAs, by which the FOA commits to catalyse the setting up of JFM groups, which is the case in Navarra.

Due to the inherent public supervision, this instrument usually improves transparency in the organisation, and increases institutional trust owing to public accountability requirements. Furthermore, the involvement of forest technicians with enduring professional horizons permits a long-term vision. The fairness criterion is more likely to be considered when a public servant leads the joint planning. However, public provision might overlook the intermediary efficiency (which may not necessarily mean durability issues for the group). The group managing technician is top-down assigned, hence removing an element of freedom in decision-making.

\subsubsection{Forest societies}

With the recent amendment of the Spanish Forest Act (law 21/ 2015), a new legal figure for private JFM is established. The "Forest Society" aims to reactivate the forestry sector through fiscal incentives to those forest owners who cede their forest use rights for twenty years or more to a company of which they become shareholders. The idea is that they become for-profit partnerships between forestry companies and landowners with attractive fiscal benefits. Klosowski et al. (2001) found fiscal benefits as relevant motivational factors, while Jacobson et al. (2000) did not. For example, the current regular fiscal system in Spain does not incentivise joint sales: $33 \%$ taxes apply if the wood is sold through a company and only $8.6 \%$ if the individual landowner sells the wood occasionally (Reimunde Noreña, 2015). The autonomous communities should define the details of Forest Societies, as well as their related economic incentives. At the State level, these companies will enjoy $10 \%$ tax relief in forest expenditures or investments.

In the current context, with predominance of inactive landowners, and a few who share costs or sale jointly in the best case (e.g. current associations, certification groupings), this figure is seen as suspicious. "Forest Societies" are drawn from SOFOR (Societies of Forest Promotion), created in Galicia through the decree 45/2011. Since then, only five companies have registered under this legal figure, which illustrates the hesitancy towards ceding these property rights. Work is still needed to increase the acceptance of this mechanism. Lessons could be extracted from the Finnish experience with Jointly Owned Forests (Lähdesmäki et al., 2016).

The lack of detailed design of the "Forest Societies" precludes from evaluating their role in mitigating JFM challenges. Yet, in general terms, they aim at deep integration in the internal decision-making process, and explicitly tackle fiscal difficulties. They constrain FOs to long-term commitments; however, this is to be compensated through promising future opportunities, and an encouraging long-term vision. Such a level of integration implies risk pooling and chances for freeriding, hence requiring strong internal trust.

\subsubsection{Policy tools discussion}

Existing policy tools in some regions of Spain specifically tackle the economic hurdles of JFM. We note the potential of the new legal enterprise of "Forest Societies", a new business model that directly addresses some economic barriers (i.e. softer taxation). However, this figure needs further development to analyse e.g. the flexibility and long-term aspects. 
Except for strong supervision through the public provision of a facilitator, policy tools can only have an indirect impact on challenges referring to internal group governance. For example, trust requires recurrent interaction. Training days, open field visits and joint input purchases are activities providing opportunities for neighbouring landowners to meet and initiate "soft" levels of collaboration. In addition, dynamising the overall group of members is necessary for achieving a progressive personal engagement in the management board. Current instruments show synergies with the local idiosyncrasy only sometimes for public provision.

Policy tools themselves can represent a window of opportunity to launch grouped management. Some Spanish regions have taken advantage of the conjunctures providing windows of opportunity to group landowners through specific subsidy design features.

Some challenges are hardly addressed by any policy tool (e.g. communication, fairness versus efficiency). These are less technicaloriented and mostly refer to the internal governance of the landowners' group, hence policy tools could only impact indirectly. In this respect, we recommend prospective policy tools offering opportunities for forest owners to interact, support in facilitation techniques, or specific training for practitioners. Approaches that facilitate the participation of smaller landowners can help in balancing fairness while searching for efficient joint solutions. For instance, solutions like facilitation of forest mapping and inventories, management planning costs, or bonuses for smaller parcels can make the group approach more attractive for the smallest while maintaining overall efficiency. Yet, some facilitation may also be required to reach agreements leading to improvement situations. Such facilitation would also need the integration of elements of rural diplomacy (e.g. local idiosyncrasy), group dynamics, and conflict resolution. These skills can be deployed through specific training for current forest technicians or through external professional facilitators.

\section{Conclusion}

Joint forest management has been found to reduce members' transaction costs and increase geographic coherence of forestry interventions. From a weak or inexistent network of communication among private forest owners, forest groupings aim to establish operative collaboration platforms.

The review of previous scholars displays twelve challenges from various domains, namely: legal, administration, communication, sociology and economics. We put forward that, by considering them in the JFM design and implementation, the likelihood of successful and endurable coordination will increase. As expected for actions requiring cooperation, some of the challenges rely on social capital theory. Moreover, JFM groupings constitute new institutions and, as such, the challenges conform to Ostrom's working rules.

Our findings show that, while existing policy tools in Spain tackle JFM economic challenges directly, they only have a limited and indirect impact on internal dynamics and decision-making process challenges. This suggests that the active role of managers in facilitating group dynamics and internal governance processes is crucial to bolster JFM initiatives.

There is no one-size-fits-all recipe and the functioning of the group requires commitment from its members to cope with these challenges. Yet, a portfolio of internal governance arrangements and their consequences could better help group managers and developers in facing business models and internal organisational aspects.

\section{Acknowledgements}

This work has been conducted within the European FP7 VALERIE Project (grant nr. 613825). We are indebted to participating landowners, to Carlos González Andrés (Xunta de Galicia), Ricard Farriol, Joan Manel Batiste, Juan Miguel Villarroel, Giuseppe Tripodi, Sarah
Adams and Claire Baradez. We also thank the editor and anonymous reviewers for their constructive comments.

\section{Appendix A. Supplementary data}

Supplementary data to this article can be found online at https:// doi.org/10.1016/j.forpol.2017.11.005.

\section{References}

Ambrosio Torrijos, Y., Picos Martin, J., Valero Gutiérrez del Olmo, E., 2003. Small nonindustrial forest owners' cooperation examples in Galicia (NW Spain). In: Forest Operation Improvements in Farm Forests, Logarska Dolina, Slovenia, pp. 9-14.

Aruga, K., Hiyamizu, G., Nakahata, C., Saito, M., 2013. Effects of Aggregating Forests, Establishing Forest Road Networks, and Mechanization on Operational Efficiency and Costs in a Mountainous Region in Japan. pp. 24. http://dx.doi.org/10.1007/s11676013-0414-1.

Avdibegović, M., Petrović, N., Nonić, D., Posavec, S., Maric, B., Vuletić, D., 2010. Readiness of private forest owners in Croatia, Serbia and Bosnia-Herzegovina to cooperate in forest roads construction and maintenance [Spremnost privatnih šumoposjednika u Hrvatskoj, Srbiji i Bosni i Hercegovini na suradnju pri izgradnji i održavanju šum]. Sumar. List CXXXIV, 55-64.

Berlin, C., Lidestav, G., Holm, S., 2006. Values placed on forest property benefits by Swedish NIPF owners: differences between members in forest owner associations and non-members. Small Scale For. Econ. Manag. Policy 5, 83-96.

Bodin, Ö., Crona, B.I., 2009. The role of social networks in natural resource governance: what relational patterns make a difference? Glob. Environ. Chang. 19, 366-374. http://dx.doi.org/10.1016/j.gloenvcha.2009.05.002.

Bodin, Ö., Prell, 2011. Social Networks and Natural Resource Management: Uncovering the Social Fabric of Environmental Governance. Cambridge University Press, New York. http://dx.doi.org/10.1080/1943815X.2012.741980.

Bouriaud, L., 2007. Property rights characteristics relevant for innovation and enterprise development in small-scale forestry. Small-scale For. 6, 359-372. http://dx.doi.org/ 10.1007/s11842-007-9027-x.

Bowles, S., Gintis, H., 2002. Social capital and community governance. Econ. J. 112, F419-F436. http://dx.doi.org/10.1111/1468-0297.00077.

Brabänder, H.D., 1981. Subsidies and efficiency in forestry co-operatives. Silva Fenn. 15, $79-84$.

Campbell, S.M., Kittredge, D.B., 1996. Application of an ecosystem-based approach to management on multiple NIPF ownerships: a pilot project. J. For. 94, 24-29.

Canadas, M.J., Novais, A., Marques, M., 2016. Wildfires, forest management and landowners' collective action: a comparative approach at the local level. Land Use Policy 56, 179-188. http://dx.doi.org/10.1016/j.landusepol.2016.04.035.

Coleman, J.S., 1988. Social capital in the creation of human capital. Am. J. Sociol. 94, 95-120.

Collaboration for Environmental Evidence, 2013. Guidelines for Systematic Review and Evidence Synthesis in Environmental Management. Version 4.2.

Cots, F., Viñas, P., 2013. Estudio de modelos de agrupación de productores y propietarios forestales: análisis de figuras jurídicas y regímenes de fiscalidad. Solsona (Lleida).

Couture, S., Cros, M., Sabbadin, R., 2016. Risk aversion and optimal management of an uneven-aged forest under risk of windthrow: a Markov decision process approach. J. For. Econ. 25, 94-114. http://dx.doi.org/10.1016/j.jfe.2016.08.002.

Dedeurwaerdere, T., 2009. Social learning as a basis for cooperative small-scale forest management. Small Scale For. 8, 193-209. http://dx.doi.org/10.1007/s11842-0099075-5.

Domínguez, G., Shannon, M., 2011. A wish, a fear and a complaint: understanding the (dis)engagement of forest owners in forest management. Eur. J. For. Res. 130, 435-450. http://dx.doi.org/10.1007/s10342-009-0332-0.

Eggers, J., Lämås, T., Lind, T., Öhman, K., 2014. Factors influencing the choice of management strategy among small-scale private forest owners in Sweden. Forests 5 , 1695-1716. http://dx.doi.org/10.3390/f5071695.

Elyakime, B., Cabanettes, A., 2009. How to improve the marketing of timber in France? For. Policy Econ. 11, 169-173. http://dx.doi.org/10.1016/j.forpol.2009.01.001.

Eyvindson, K., Kurttila, M., Hujala, T., 2011. An internet-supported planning approach for joint ownership forest holdings. Small Scale For. 1-17. http://dx.doi.org/10.1007/ s11842-010-9123-1.

Finley, A., Kittredge, D.J., Stevens, T., Schweik, C., Dennis, D., 2006. Interest in crossboundary cooperation: identification of distinct types of private forest owners. For. Sci. 52, 10-22.

Fischer, A.P., Charnley, S., 2012. Risk and cooperation: managing hazardous fuel in mixed ownership landscapes. Environ. Manag. 49, 1192-1207. http://dx.doi.org/10. 1007/s00267-012-9848-z.

Forest Europe, 2015. State of Europe's Forests. pp. 2015.

Glück, P., Avdibegović, M., Čabaravdić, A., Nonić, D., Petrović, N., Posavec, S., Stojanovska, M., 2010. The preconditions for the formation of private forest owners' interest associations in the Western Balkan Region. For. Policy Econ. 12, 250-263. http://dx.doi.org/10.1016/j.forpol.2010.02.001.

Górriz-Mifsud, E., Secco, L., Pisani, E., 2016. Exploring the interlinkages between governance and social capital: a dynamic model for forestry. For. Policy Econ. 65, 25-36. http://dx.doi.org/10.1016/j.forpol.2016.01.006.

Gorriz-Mifsud, E., Marini Govigli, V., Bonet, J.A., 2017. What to do with mushroom pickers in my forest? Policy tools from landowners' perspective. Land Use Policy 63, 450-460. http://dx.doi.org/10.1016/j.landusepol.2017.02.003. 
Hägglund, D., 2008. European forest owner organisations. In: Forest Owner Cooperation: Main Figures, Aims and Goals.

Hansmann, R., Kilchling, P., Seeland, K., 2016. The effects of regional forest owner organizations on forest management in the Swiss canton of Lucerne. Small-scale For. 15, 159-177. http://dx.doi.org/10.1007/s11842-015-9315-9.

Jacobson, M.G., Abt, R.C., Carter, D.R., 2000. Attitudes toward joint forest planning among private landowners. J. Sustain. For. 11, 95-112. http://dx.doi.org/10.1300/ J091v11n03_06.

Karppinen, H., Horne, P., Hujala, T., Leppänen, J., Matilainen, A., Talkkari, A., 2015. Forest Land Ownership Change in Finland, Vienna. Doi: http://dx.doi.org/10.13140/ RG.2.1.1891.8569.

Kindstrand, C., Norman, J., Boman, M., Mattsson, L., 2008. Attitudes towards various forest functions: a comparison between private forest owners and forest officers. Scand. J. For. Res. 23, 133-136. http://dx.doi.org/10.1080/02827580801944842.

Kittredge, D.B., 2005. The cooperation of private forest owners on scales larger than one individual property: international examples and potential application in the United States. For. Policy Econ. 7, 671-688.

Klosowski, R., Stevens, T., Kittredge, D., Dennis, D., 2001. Economic incentives for coordinated management of forest land: a case study of southern New England. For. Policy Econ. 2, 29-38. http://dx.doi.org/10.1016/S1389-9341(00)00035-6.

Koch, S.P., Schwarzbauer, P., Stern, T., 2013. Monthly wood supply behavior of associated forest owners in Austria-insights from the analysis of a micro-econometric panel. J. For. Econ. 19, 331-346. http://dx.doi.org/10.1016/j.jfe.2013.06.003.

Kronholm, T., 2016. How are Swedish forest owners associations adapting to the needs of current and future members and their organizations? Small-scale For. 15, 413-432. http://dx.doi.org/10.1007/s11842-016-9330-5.

Kronholm, T., Wästerlund, D.S., 2013. District council members and the importance of member involvement in organization renewal processes in Swedish forest owners' associations. Forests 4, 404-432. http://dx.doi.org/10.3390/f4020404.

Kueper, A.M., Sagor, E.S., Becker, D.R., 2013. Learning from landowners: examining the role of peer exchange in private landowner outreach through landowner networks. Soc. Nat. Resour. 26, 912-930. http://dx.doi.org/10.1080/08941920.2012.722748.

Lähdesmäki, M., Matilainen, A., 2014. Born to be a forest owner? An empirical study of the aspects of psychological ownership in the context of inherited forests in Finland. Scand. J. For. Res. 29, 101-110. http://dx.doi.org/10.1080/02827581.2013.869348.

Lähdesmäki, M., Matilainen, A., Siltaoja, M., 2016. Legitimating institutional choices in the forest ownership: building acceptability for jointly owned forests. Eur. J. For. Res. http://dx.doi.org/10.1007/s10342-016-0993-4.

Lidestav, G., Arvidsson, A.-M., 2012. Member, owner, customer, supplier? The question of perspective on membership and ownership in a private forest owner cooperative. In: Okia, C.A. (Ed.), Global Perspectives on Sustainable Forest Management. InTech, pp. 75-94.

McGill, D.W., Grushecky, S.T., Moss, S., Pierskalla, C., Schuler, A., 2008. Landowner willingness to engage in long-term timber leases in West Virginia, USA. Small Scale For. 7, 105-116. http://dx.doi.org/10.1007/s11842-008-9044-4.

Mendes, A.M.S.C., 2006. Forest owners' organizations in Portugal: are the infant going to survive? In: Wall, E. (Ed.), Small-scale Forestry and Rural Development: The Intersection of Ecosystems, Economics and Society. IUFRO 3.08 Meeting. Galway, Ireland, pp. 289-304.

Mendes, A.M.S.C., Feliciano, D., Tavares, M., Dias, R., 2004. The Portuguese Forests.

Mendes, A.M.S.C., Størdal, S., Adamczyk, W., Bancu, D., Bouriaud, L., Feliciano, D., Gallagher, R., Kajanus, M., Mészáros, K., Schraml, U., Venzi, L., 2006. Forest owners' organizations across Europe: similarities and differences. In: Niskanen, A. (Ed.), Issues Affecting Enterprise Development in the Forest Sector in Europe. University of Joensuu, pp. 84-104.

Mendes, A.M.S.C., Stefanek, B., Feliciano, D., Mizaraite, D., Nonic, D., Kitchoukov, E., Nybakk, E., Duduman, G., Weiss, G., Nichiforel, L., Stoyanova, M., Mäkinen, P., Alves, R., Milijic, V., Sarvašová, Z., 2011. Institutional innovation in European private forestry: the emergence of forest owners' organizations. In: Weiss, G., Pettenella, D., Ollonqvist, P., Slee, B. (Eds.), Innovation in Forestry. Territorial and Value Chain Relationships. CABI International, pp. 68-86.

Milijic, V., Rankovic, N., Nonic, D., Nedeljkovic, J., 2010. Organization of private forest sector in Timok forest area. Ann. For. Res. 53, 59-69.

Navascués Ramos, P., Llobet Just, S., 2007. La gestión de montes privados en regeneración a través de asociaciones de propietarios forestales. Cuad. la Soc. Española Ciencias For. 21, 61-66.

Nonic, D., Bliss, J.C., Milijic, V., Petrovic, N., Avdibegovic, M., Mataruga, M., 2011. Challenges of organizing private forest owners in Serbia. Small Scale For. 10, 435-455. http://dx.doi.org/10.1007/s11842-011-9160-4.

Ostrom, E., 1990. Governing the Commons: The Evolution of Institutions for Collective Action. Cambridge University Press, Cambridge, UK.

Ostrom, E., 2005. Doing institutional analysis digging deeper than markets and hierarchies. In: Ménard, C., Shirley, M.M. (Eds.), Handbook of New Institutional Economics. Springer, pp. 819-848.

Ostrom, E., 2010. Beyond markets and states: polycentric governance of complex economic systems. Am. Econ. Rev. 100, 641-672.

Ostrom, E., Ahn, T.K., 2009. The meaning of social capital and its link to collective action. In: Svendsen, G.T., Svendsen, G.L.H. (Eds.), Handbook of Social Capital. The Troika of Sociology, Political Science and Economics. Edward Elgar Publishing, pp. 253-279.
Ota, I., 2007. A forest owners' cooperative in Japan: benefits for small-scale forests. Unasylva 58, 64-66.

Pezdevšek Malovrh, Š., Hodges, D.G., Maric, B., Avdibegović, M., 2011. Private forest owner expectations of interest associations: comparative analysis between Slovenia and Bosnia-Herzegovina. Sumar. List 9-10, 1-10.

Pezdevšek Malovrh, Š., Nonić, D., Glavonjić, P., Nedeljković, J., Avdibegović, M., Krč, J., 2015. Private forest owner typologies in Slovenia and Serbia: targeting private forest owner groups for policy implementation. Small Scale For. 423-440. http://dx.doi. org/10.1007/s11842-015-9296-8.

Põllumäe, P., Korjus, H., Kaimre, P., Vahter, T., 2014. Motives and incentives for joining forest owner associations in Estonia. Small-scale For. 13, 19-33. http://dx.doi.org/ 10.1007/s11842-013-9237-3.

Põllumäe, P., Lilleleht, A., Korjus, H., 2016. Institutional barriers in forest owners' cooperation: the case of Estonia. For. Policy Econ. 65, 9-16. http://dx.doi.org/10. 1016/j.forpol.2016.01.005.

Pretty, J., 2003. Social capital and the collective management of resources. Science 302 (80), 1912-1914. http://dx.doi.org/10.1126/science.1090847.

Primmer, E., Karppinen, H., 2010. Professional judgment in non-industrial private forestry: forester attitudes and social norms influencing biodiversity conservation. For. Policy Econ. 12, 136-146. http://dx.doi.org/10.1016/j.forpol.2009.09.007.

Prokofieva, I., Górriz, E., 2013. Institutional analysis of incentives for the provision of forest goods and services: an assessment of incentive schemes in Catalonia (north-east Spain). For. Policy Econ. 37, 104-114.

Reimunde Noreña, R., 2015. The initiatives of forest cooperation in Galicia: the case of PROMAGAL. In: SIMWOOD Workshop on Wood Mobilisation: The Role of Forest Cooperatives. Waterford, Ireland.

Rickenbach, M.G., Guries, R.P., Schmoldt, D.L., 2006. Membership matters: comparing members and non-members of NIPF owner organizations in southwest Wisconsin, USA. For. Policy Econ. 8, 93-103. http://dx.doi.org/10.1016/j.forpol.2004.05.006.

Rodríguez-Vicente, V., Marey-Pérez, M.F., 2009. Characterization of nonindustrial private forest owners and their influence on forest management aims and practices in Northern Spain. Small Scale For. 8, 479-513. http://dx.doi.org/10.1007/s11842009-9097-z.

Rojo Alboreca, A., 2013. El reto de la ordenación de montes privados en España. In: 60 Congreso Forestal Español. Montes: Servicios Y Desarrollo ruralCongreso Forestal Español. Servicios Y Desarrollo Rural. Sociedad Española de Ciencias Forestales, Vitoria, Montes, pp. 30.

Sálka, J., Dobsinská, Z., Hricová, Z., 2016. Factors of political power - the example of forest owners associations in Slovakia. For. Policy Econ. 68, 88-98. http://dx.doi. org/10.1016/j.forpol.2015.05.003.

Sarvašová, Z., Cienciala, E., Beranová, J., Vančo, M., Ficko, A., Pardos, M., 2014. Analysis of governance systems applied in multifunctional forest management in selected European mountain regions Analýza systémov governancie využívaných pri multifunkčnom manažmente lesov vo vybraných európskych horských oblastiach. Lesn. Cas. For. J. 60, 159-167.

Sarvasova, Z., Zivojinovic, I., Weiss, G., Dobsinská, Z., Dragoi, M., Gál, J., Jarský, V., Mizaraite, D., Põllumäe, P., Sálka, J., Schiberna, E., Sisák, L., Wolfslehner, B., Zalite, Z., Zalitis, T., 2015. Forest owners associations in the Central and Eastern European Region. Small Scale For. 14, 217-232. http://dx.doi.org/10.1007/s11842-0149283-5.

Schlüter, A., Koch, M., 2009. Institutional change in the forest sector: trust and mental models. Eur. J. For. Res. 130, 383-393. http://dx.doi.org/10.1007/s10342-0090333-z.

Schraml, U., 2005. Between legitimacy and efficiency: the development of forestry associations in Germany. Small Scale For. Econ. Manag. Policy 4, 251-267. http://dx. doi.org/10.1007/s11842-005-0016-7.

Schubert, J.R., Mayer, A.L., 2012. Peer influence of non-industrial private forest owners in the Western Upper Peninsula of Michigan. Open J. For. 2, 147-155. http://dx.doi. org/10.4236/ojf.2012.23018.

Sundar, N., 2000. Unpacking the "joint" in joint forest management. Dev. Chang. 31, 255-279.

UE, 2013. Reglamento (UE) 1305/2013 del Parlamento Europeo y del Consejo de 17 de diciembre de 2013 relativo a la ayuda al desarrollo rural a través del Fondo Europeo Agrícola de Desarrollo Rural (FEADER) y por el que se deroga el Reglamento (CE) no $1698 / 2005$ del C.

Van Gossum, P., Luyssaert, S., Serbruyns, I., Mortier, F., 2005. Forest groups as support to private forest owners in developing close-to-nature management. For. Policy Econ. 7, 589-601. http://dx.doi.org/10.1016/j.forpol.2003.10.003.

Van Herzele, A., Aarts, N., 2013. "My forest, my kingdom" - self-referentiality as a strategy in the case of small forest owners coping with government regulations. Policy. Sci. 46, 63-81. http://dx.doi.org/10.1007/s11077-012-9157-7.

Weiss, G., Gudurić, I., Wolfslehner, B., 2012. Review of Forest Owners' Organizations in Selected Eastern European Countries (No. 30), Forestry Policy and Institutions Working Papers. Rome.

Weiss, G., Aggestam, F., Hogl, K., Jandl, R., Živojinović, I., Ludvig, A., Wolfslehner, B., 2015. Forest Land Ownership Change in Austria, Vienna. http://dx.doi.org/10. 13140/RG.2.1.1891.8569.

Wondolleck, J.M., Yaffee, S.L., 2000. Making Collaboration Work: Lessons from Innovation in Natural Resources Management. Island Press, Washington, DC. 